\title{
$\mathrm{MCL}$ 알고리즘을 이용한 단백질 표면의 바인딩 영역 분석 기법 \\ 정 광 수 $^{+}$유 기 진 $^{\dagger} \cdot$ 정 용 제 ${ }^{++} \cdot$ 류 근 호 $^{++}$ \\ 요 약
}

\begin{abstract}
단백질은 다른 물질과의 결합하여 기능을 수행하기 때문에 활성 사이트가 유사한 단백질은 유사한 기능을 가진다. 따라서 단백질의 바인딩 영역을 식별함으로써 단백질의 기능을 추론할 수 있다. 이 논문은 MCL (Markov Cluster) 알고리즘을 이용하여 단백질의 바인딩 영역을 추출 하는 새로운 방법을 제시한다. 이를 위하여 단백질의 표면 잔기 거리를 나타내는 distance matrix를 생성하고, 여기에 MCL 프로세스를 적용한 다. 제시한 방법을 평가하기 위해 Catalytic Site Atlas (CSA) 데이터를 사용하였다. CSA 데이터 (94개의 단일 체인 단백질)를 이용한 실험 결 과, 알고리즘은 91 개 단백질의 활성 사이트 주변의 바인딩 영역을 검출하였다. 이 논문은 단백질 활성 사이트를 분석하기 위한 새로운 기하학 적 특징을 제시하였고, 활성 사이트와 관련이 없는 잔기를 제거함으로써 단백질 표면의 분석의 시간을 줄일 수 있는 장점이 있다
\end{abstract}

키워드 : 단백질 구조, 표면, 바이오인포매틱스, MCL 알고리즘

\section{Investigating Binding Area of Protein Surface using MCL Algorithm}

\author{
Kwang Su Jung ${ }^{\dagger} \cdot \mathrm{Ki}$ Jin $\mathrm{Yu}^{\dagger} \cdot$ Yong Je Chung ${ }^{+\dagger} \cdot \mathrm{Keun} \mathrm{Ho} \mathrm{Ryu}^{+++}$
}

\begin{abstract}
Proteins combine with other materials to achieve their function and have similar function if their active sites are similar. Thus we can infer the function of protein by identifying the binding area of proteins. This paper suggests the novel method to select binding area of protein using MCL (Markov Cluster) algorithm. We construct the distance matrix from surface residues distance on protein. Then this distance matrix is transformed to connectivity matrix for applying MCL process. We adopted Catalytic Site Atlas (CSA) data to evaluate the proposed method. In the experimental result using CSA data (94 selected single chain proteins), our algorithm detects the 91 (97\%) binding area near by active site of each protein. We introduced a new geometrical features and this mainly contributes to reduce the time to analyze the protein by selecting the residues near by active site.
\end{abstract}

Key Words : Protein Strucure, Surface, Bioinformatics, MCL Algoritm

\section{1. 서 론}

단백질은 생명체에서 주요 핵심 역할을 담당한다. 생명체 의 생물학적 기능과 과정을 밝히기 위해서 단백질은 다양한 방법으로 분석되었다. 단백질 분석 방법 중 단백질 서열 분 석을 이용한 상동성 비교는 쉽고 빠르게 비교할 수 있지만, 상동성이 낮은 경우는 예측이 어렵다. 서열 분석을 이용하 여 예측이 불가능한 경우는 폴드 분석을 실행하게 된다. 그 러나 기능이 유사하더라도 폴드가 다른 단백질이 있고[1], 유사한 폴드나 서열을 갖는 단백질도 완전히 다른 기능을

※ 이 논문은 2007년 교육인적자원부의 재원으로 한국학술진흥재단의 지원(지방 연구중심대학육성사업/충북BIT연구중심대학육성사업단)과 과학기술부의 재원 으로 한국과학재단의 지원을 받아 수행된 연구임(R01-2007-000-10926-0).

† 정 회 원 : 충북대학교 전자계산학과 연구원

†† 정 회 원: 충북대학교 생명과학부 교수

†+† 종신회원 : 충북대학교 전기전자컴퓨터공학부 교수(교신저자)

논문접수: 2007년 7월 27일, 심사완료 : 2007년 10월 27일
수행하기도 한다[2]. 따라서 이런 문제점을 보완하기 위해 기능과 밀접한 관계를 가지고 있는 특정 핵심 영역의 연구 가 필요하다[3]. 단백질 기능은 대부분 단백질 표면의 물리 적, 화학적, 기하학적 특징 등에 의해 결정되며, 유사한 폴드 라고 할지라도 단백질 표면의 활성 사이트가 다른 경우 다 른 기능을 수행할 수 있다. 단백질 표면의 서열과 공간적 패턴 분석을 통하여, 핵심 잔기와 단백질 기능과의 관계를 규명함으로써 알려지지 않은 단백질 구조의 기능을 밝힐 수 있고, 단백질 표면과 기능의 새로운 관계를 발견할 수 있다. 단백질은 기질, 리간드, RNA, 단백질 등의 물질과 결합하여 기능을 수행하고, 이 중 효소는 리간드와 결합하는 단백질 의 한 종류이다. 효소의 몇몇 아미노산은 효소의 촉매 작용 이 일어나는 사이트를 구성하기 때문에, 활성 사이트는 특 정 기질의 리간드와 결합하는 아미노산을 갖는다. 이 논문 은 효소를 대상으로 연구를 진행하였으며, 바인딩 영역은 리간드와 결합하는 활성 사이트 주변의 잔기들을 의미한다. 
우리는 인접한 잔기 간의 연결 형태를 이용하여 단백질 표 면에 있는 활성 사이트 주변의 바인딩 영역을 검출하는 새로 운 방법을 제시한다. 그리고 잔기의 거리 정보를 나타내는 distance matrix를 변환하여 connectivity matrix를 생성한다. connectivity matrix에서, 사용자가 정의한 거리 cut-off threshold를 만족하지 못하는 값은 무시되고 '0'으로 대체된다. 이 matrix는 MCL(markov cluster) 알고리즘의 입력 matrix로 이 용된다[4,5]. 우리는 weight factor를 설정하기 위해 Catalytic Site Atlas (CSA, http://www.ebi.ac.uk/thornton-srv/databases/CSA/) [6]를 사용하였다. CSA 데이터를 이용하여 활성 사이트 주변 의 바인딩 영역에서 빈번하게 발견되는 잔기 빈발도를 계산하 고, 바인딩 영역에서 빈발하게 발견되는 잔기는 높은 가중치 를 할당한다. 잔기들의 가중치에 대한 설명은 4장에서 자세히 설명할 것이다. 우리는 distance matrix에서 의미 있는 거리 값을 선택하기 위한 distance cut-off 값과 $\mathrm{MCL}$ 알고리즘의 다양한 inflation factor를 가지고 테스트하였다. CSA 데이터 (94개 단일 체인 단백질)를 이용하여 실험한 결과, 우리의 방 법은 91 개 단백질에서 활성 사이트 주변의 바인딩 영역을 검 출하는 결과를 보였다. 각 단백질에서 선택된 가장 좋은 클러 스터들을 보면, 대략 $70 \%$ 잔기가 실제로 바인딩 영역에 속하 는 것으로 나타났다. 다른 실험 결과와 분석은 5 장에서 자세히 설명될 것이다. 우리의 연구는 단백질 표면의 활성사이트에 관련된 새로운 기하학적 특징을 제시하였고, 이를 이용하여 활성 사이트와 관련 없는 잔기를 필터링하고, 활성 사이트 주 변의 잔기를 선택함으로써 활성 사이트 분석 시간을 줄일 수 있다. 또한, 기존의 바인딩 영역이 오목한 형태가 아니더라도 제안한 방법을 적용하면, 바인딩 영역예측이 가능하다.

\section{2. 관련연구}

단백질 서열 분석과 구조 분석은 서열과 구조의 유사성이 낮음에도 불구하고 유사한 기능을 수행하는 단백질의 경우 기능을 정확하게 예측할 수 없다[7, 8]. 따라서 구조와 특징 에 의해 단백질 기능을 결정하는 활성 사이트의 분석이 많 이 이루어지고 있다. 이 절에서는 활성 사이트를 분석하여 단백질의 기능을 예측하는 기법들을 소개한다.

활성 사이트의 구조를 분석한 Fabian Glaser[9]는 SURFNET[10] 프로그램을 통해 표면의 가장 큰 포켓(pocket) 4개를 선택하 고, 그 중 활성 사이트를 포함하는 포켓을 식별하는 방법을 제안하였다. 활성 사이트를 포함하는 포켓은 결합 물질보다 크며, 효소는 기질과 보조인자 등 하나 이상의 물질과 결합한 다. 따라서 정확한 활성 사이트 크기를 이용하여 결합물질을 밝히기 위해 Consurf-HSSP(Homology-Derived Secondary Structure of Proteins) 데이터베이스에서 잔기의 보존율을 측정하고, 보존율이 높은 중요한 잔기와 거리가 먼 잔기를 제거하였다. 이 방법은 SURFNET의 초기 포켓 부피와 아 미노산 잔기 수를 감소시켜 더 정확한 활성 사이트의 형태 와 포켓 내의 위치를 예측한다.

Changhui Yan[11]은 구조 정보 없이 활성 사이트 아미노
산 잔기와 서열상의 주변 아미노산 잔기를 이용하여 분석하 였다. 또한 DSSP(Database of Secondary Structure in Proteins) 프로그램을 이용하여 단백질 표면의 면적을 나타 내는 ASA(solvent Accessible Surface Area)를 측정하였다. 단백질 표면과는 다른 특징을 가지는 활성 사이트 아미노산 잔기의 성질과 측정한 $\mathrm{ASA}$ 를 이용하여, 표면보다 빈발한 아미노산 잔기의 물리화학적 특징을 추출하였다. 추출된 특 징은 지식기반 분류기(SVM : Support Vector Machine)를 통해 활성 사이트의 아미노산 잔기를 분류하는데 이용된다. 이 논문에서는 서열상의 주변 아미노산 잔기를 선택하지 않 고 폴드상의 주변 아미노산 잔기를 이용한다.

T.Andrew Binkowski[12]는 CASTp(Computed Atlas of Surface Topography of proteins) 데이터베이스에서 포켓의 정보를 추출하여 분석하였다. 표면과 포켓을 구성하는 아미 노산 잔기 특성을 분석한 결과, 포켓에서는 방향성 아미노 산 잔기와 소수성 아미노산 잔기가 비교적 많이 분포하고, 표면에서는 극성 아미노산 잔기가 많이 분포한다. 그리고 포켓을 구성하는 아미노산 잔기의 서열 보존율은 다른 부분 보다 더 높게 측정되었다. 포켓의 형태를 비교하기 위해, 아 미노산 잔기의 위치를 나타내는 $\mathrm{cRMSD}$ 와 잔기의 벡터를 나타내는 $\mathrm{oRMSD}$ 를 계산하였다.

Oliviero Carugo[13]는 고유벡터(eigenvector)와 고유치 (eigenvalue)를 이용하여 단백질 표면 패치(patch)를 분석하 고, 중심 원자와 그 주변의 40 개 원자로 구성된 패치의 고 유벡터를 통해 단백질 표면을 비교하였다. 41 개 원자의 $\mathrm{x}$, $\mathrm{y}, \mathrm{Z}$ 좌표는 $41 \times 3$ 행렬 $\mathrm{D}$ 로 표현하고, $\mathrm{D}$ 의 전치행렬을 이용 하여 $3 \times 3$ 행렬 $Z$ 로 변환한다. 행렬 $Z$ 를 통해 계산된 고유치 는 41 개 원자가 분산되어있는 정도를 나타내고, 각 패치의 고유치를 이용하여 패치의 형태를 비교하였다. Oliviero Carugo는 41개의 원자를 선택한 반면, 우리는 각 바인딩 잔 기 주변의 아미노산 잔기 20개를 선택한다.

Susan Jones[14]는 일반적으로 단백질-단백질 상호작용의 결합 부위인 interface의 형태와 $\triangle \mathrm{ASA}$, 아미노산 잔기 특징, 소수결합 등의 정보를 분석하였다. $\triangle \mathrm{ASA}$ 는 monomer의 $\mathrm{ASA}$ 와 complex 형성 후의 $\mathrm{ASA}$ 차이를 나타내는 것으로, homodimer와 heterocomplex의 $\triangle \mathrm{ASA}$ 차이를 분석하였다. interface의 평평한 정도를 분석하기 위해 $\mathrm{dRMSD}$ 를 계산한 결과, heterocomplex interface는 움푹 들어간 형태인 반면, homodimer는 울퉁불퉁한 형태임을 밝혔다. 표면에 분포하 는 특정 아미노산 잔기의 $\mathrm{ASA}$ 와 interface에 분포하는 특정 아미노산 잔기 $\mathrm{ASA}$ 비율은 특정 잔기 분포정도를 나타낸 다. 이를 통해 interface에는 표면보다 소수성 아미노산 잔기 가 많이 분포하는 것을 밝혔다. 이 논문에서는 Susan Jones 의 물리화학적 특징을 계산하는 식을 변형하여 아미노산 잔 기 분포 정도를 밝힌다.

이 논문에서 사용되는 $\mathrm{MCL}$ 알고리즘 $[4,5]$ 은 그래프에서 랜덤 워크와 flow 시뮬레이션을 기반으로 한 빠른 그래프 클러스터링 알고리즘이다. 특히, 간단한 그래프와 가중치가 있는 간선이 표기된 그래프를 다루기 위해 설계되어, 그래 프 클러스터링 분야에서 사용되어왔다. 

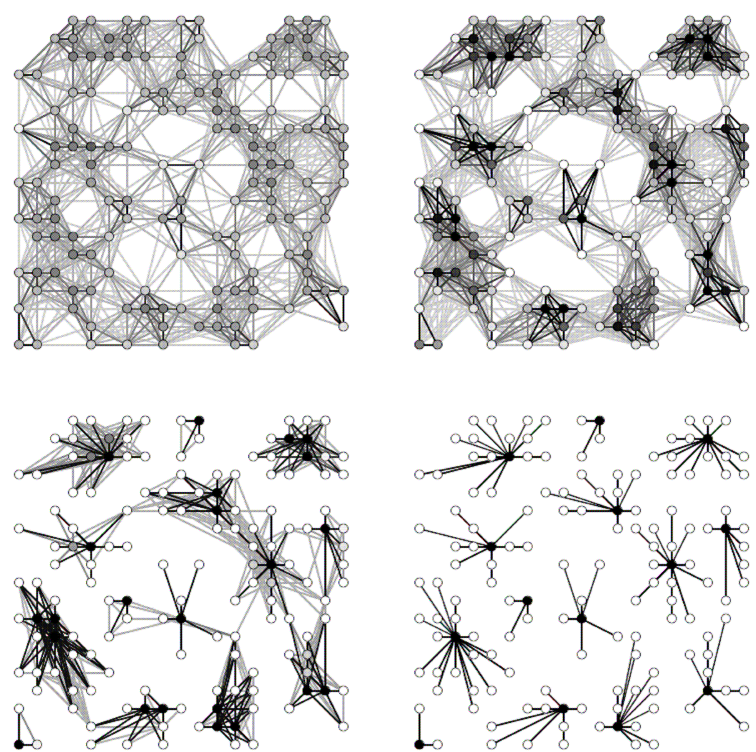

(그림 1) MCL process에 의한 flow 시뮬레이션 단계

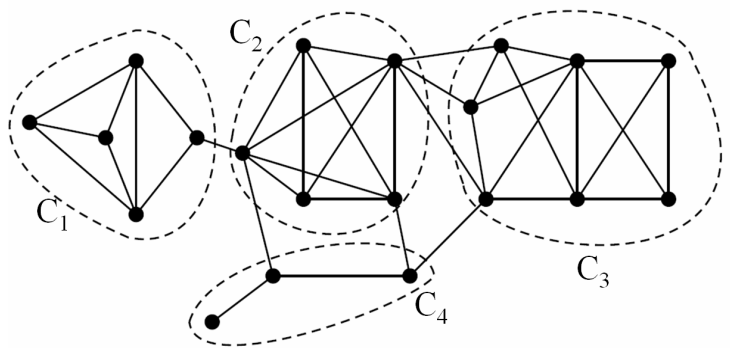

(그림 2) connectivity graph $\mathrm{G}$ 의 예

$\mathrm{MCL}$ process를 나타낸 (그림 1)에서 반복적인 단계는 왼 쪽에서 오른쪽 방향으로, 위에서 아랫방향으로 이루어진다. 왼쪽 상단의 그래프는 $\mathrm{MCL}$ process 전의 처음 단계이고, 오 른쪽 하단의 그래프는 flow가 한계에 이르러 $\mathrm{MCL}$ process가 종료된 상태이다. 검은 노드는 어트랙터(attractor)를 나타내 며, 이는 검은 노드를 중심으로 다른 흰색 노드들을 끌어당 기고 있는 것을 연결 형태를 나타내고 있다. 즉, 오른쪽 하단 의 그래프는 $\mathrm{MCL}$ 알고리즘을 적용한 그래프 클러스터링의 결과를 나타내며, 연결된 노드들을 클러스터링한 것이다.

$\mathrm{MCL}$ 알고리즘은 expansion과 inflation 연산이 반복적으 로 수행함으로써 랜덤 워크가 이루어진다. (그림 2)에서 각 각의 노드들은 다른 노드와의 연결 정보를 가지고 있고, 가 중치가 높은 노드는 높은 값을 가지고 있다. 이는 matrix 형태로 표현이 가능하다. 그림 2 에서의 $\mathrm{C}_{1}, \mathrm{C}_{2}, \mathrm{C}_{3}$ 와 $\mathrm{C}_{4}$ 는 $\mathrm{MCL}$ 알고리즘을 이용하여 클러스터링된 결과를 나타낸다. 그림 3은 $\mathrm{MCL}$ process의 단계이다.

Expansion은 표준 matrix 제곱(product)을 이용하여 확률 matrix의 제곱을 취하여 계산된다. (그림 3)에서의 확률 matrix (Markov Matrix, M)의 한 열(column)은 음수가 아닌 각 cell value로 구성되고, 한 열의 각 셀 값의 합이 1 이다. $\mathrm{M}$ $\geq 0$ 을 만족하는 $\mathrm{M} \in \mathrm{R}^{\mathrm{kxk}}$ matrix와 $\mathrm{r}>1$ 의 real number를
1. 그래프 $\mathrm{G}$ 를 이용하여 Graph Matrix GM 생성

2. GM을 확률적 Markov matrix M으로 변환

3. $\mathrm{M}=\mathrm{M}^{2}$ (Expansion)

4. $\mathrm{M}=\Gamma_{r} M$ (Inflation)

5. 만약 $\mathrm{M} \neq \mathrm{M}^{2}$ 이라면, 3 단계와 4단계 반복. $\mathrm{M}=\mathrm{M}^{2}$ 이라면, 중단.

(그림 3) MCL Process

이용하여, 제곱 계수 $\mathrm{r}$ 을 열의 각 cell value에 취하여 산출 된 한 열의 확률 matrix는 $\Gamma_{r} M$ 이다. $\Gamma_{r}$ 은 식 (1)에서 제 곱 계수 $\mathrm{r}$ 을 이용하는 inflation 연산자이다. Expansion 과 inflation 단계를 되풀이 하면서, 한 단계의 expansion 과 inflation 이 끝날 때 마다, matrix는 한 열의 셀의 합이 1 인 확률 matrix 형태로 변형되고, 이를 다음단계의 $\mathrm{MCL}$ process에 이용한다.

$$
\left(\Gamma_{r} M\right)_{p q}=\left(M_{p q}\right)^{r} / \sum_{i=1}^{k}\left(M_{i q}\right)^{r}
$$

확률 matrix $\mathrm{M}$ 의 각 열 $\mathrm{j}$ 는 $\mathrm{M}$ 과 관련된 확률 그래프의 $\mathrm{j}$ 노드와 일치한다. $\mathrm{j}$ 열의 $\mathrm{i}$ 행 entry (즉, $\mathrm{M}_{\mathrm{ij}}$ )는 $\mathrm{j}$ 노드에서 $\mathrm{i}$ 노 드로 흐르는 확률이다. $\mathrm{r}>1$ 의 값은, 흐름 시뮬레이션의 시작 을 나타내고, 쉽게 흐를 수 있는 노드와 덜 흐를 수 있는 노드 를 구분하여 시뮬레이션 됨으로써 클러스터링이 진행된다.

\section{3. 표면 잔기의 Distance Matrix}

선행 연구[15,16,17,18,19]의 단백질 잔기 distance matrix 는 단백질의 전체 잔기를 포함하고 단백질 폴드를 비교하기 위해 사용되었다. 이 논문에서 우리는 표면 잔기의 연결 정 보를 나타내기 위해 단백질 표면의 잔기 간의 거리를 계산 하였다. 기존의 단백질 distance matrix는 잔기의 $\mathrm{Ca}$ 의 위치 를 기준으로 distance matrix를 구성하는데 반하여, 우리는 Residue Center를 사용하였다. $\mathrm{Ca}$ 의 위치는 결국 단백질 전 체 구조의 백본을 나타내며, 기존의 distance matrix 기반의 선행 연구는 단백질 전체 구조를 사용하기 때문에 $\mathrm{Ca}$ 의 위 치를 사용하는 것이 타당하나, 우리의 경우는 단백질의 전 체 구조 보다는 기능과 밀접한 연관이 있는 표면의 특정 영 역을 대상으로 한다. Residue Center는 $\mathrm{Ca}$ 좌표를 포함한 side chain atom의 평균으로 정의된다. 대부분의 side chain 이 단백질 내부보다 표면의 방향으로 위치하기 때문에 side chain을 포함한 Residue Center는 $\mathrm{Ca}$ 위치보다 더 표면과 근접한 형태를 나타낸다.

$x$ coordinate of Residue Center

$$
=\frac{\sum_{i=1}^{n}\left(C \alpha_{x}+a x_{1}+a x_{2}+a x_{3}+\cdots+a x_{n}\right)}{n+1}
$$


식 (2)은 Residue Center의 $x$ 좌표 계산 방법이며, $y$ 와 $z$ 좌표도 동일한 방법으로 계산된다. 식 (2)에서, $\mathrm{Ca}_{x}$ 는 $\mathrm{Ca}$ 의 $x$ 좌표를 나타내고, $a x_{n}$ 은 각 side chain atom의 $x$ 좌표 를 의미한다. 우리는 표면 잔기 간의 Euclidean Distance를 계산하여 distance matrix를 생성하였다. 예로, (그림 4)의 각 cell value는 Residue Center 간의 거리를 나타낸다.

자기와의 거리를 나타내는 대각선 셀의 값은 ' 0 '을 갖고, 1 차 아미노산 서열에서 근접한 잔기는 공간상에서도 근접하 였기 때문에 낮은 값 갖는다. (그림 4)의 distance matrix는 connectivity matrix로 변환된다. 여기서, 공간상에 서로 근 접한 잔기는 높은 connectivity를 갖는다고 가정한다. 그리 고 다양한 distance cut-off value를 적용하였으며, 적용 결과 는 5절에서 소개한다. connectivity matrix는 $\mathrm{MCL}$ process의 input matrix로 사용된다. 다음 장에서 connectivity matrix 의 변환에 대해서 더 자세히 설명한다.

\begin{tabular}{|c|c|c|c|c|c|c|}
\hline & aa1 & aa2 & aa3 & aa4 & aa5 & aa6 \\
\hline aa1 & 0 & 5 & 8 & 12 & 13 & 3 \\
\hline aa2 & 5 & 0 & 6 & 9 & 8 & 20 \\
\hline aa4 & 8 & 6 & 0 & 3 & 10 & 16 \\
\hline aa4 & 12 & 9 & 3 & 0 & 2 & 8 \\
\hline aa5 & 13 & 8 & 10 & 2 & 0 & 5 \\
\hline aa6 & 3 & 20 & 16 & 8 & 5 & 0 \\
\hline
\end{tabular}

(그림 4) Distance Matrix of surface residues.

\section{MCL 알고리즘의 응용}

Distance matrix의 모든 셀 값 $\mathrm{D}_{\mathrm{ij}}$ 는 Graph Matrix $\mathrm{GM}$ 을 생성하기 위해 $1 / \mathrm{D}_{\mathrm{ij}}$ 로 변환된다. distance matrix에서는 낮은 cell value가 더 의미 있는 반면, Connectivity graph G 의 Graph Matrix GM에서 높은 cell value가 더 중요한 의미 를 갖는다. (그림 5)는 Graph Matrix GM로 변환된 distance matrix를 나타낸다.

\begin{tabular}{|c|c|c|c|c|c|c|}
\hline & aa1 & aa2 & aa3 & aa4 & aa5 & aa6 \\
\hline aa1 & 0 & $1 / 5$ & $1 / 8$ & $1 / 12$ & $1 / 13$ & $1 / 3$ \\
\hline aa2 & $1 / 5$ & 0 & $1 / 6$ & $1 / 9$ & $1 / 8$ & $1 / 20$ \\
\hline aa4 & $1 / 8$ & $1 / 6$ & 0 & $1 / 3$ & $1 / 10$ & $1 / 16$ \\
\hline aa4 & $1 / 12$ & $1 / 9$ & $1 / 3$ & 0 & $1 / 2$ & $1 / 8$ \\
\hline aa5 & $1 / 13$ & $1 / 8$ & $1 / 10$ & $1 / 2$ & 0 & $1 / 5$ \\
\hline aa6 & $1 / 3$ & $1 / 20$ & $1 / 16$ & $1 / 8$ & $1 / 5$ & 0 \\
\hline
\end{tabular}

(그림 5) connectivity Graph Matrix GM로 변환된 distance matrix
그러나 여기서 (그림 5)의 대각선상의 '0' cell value를 어 떻게 설정할 지의 문제가 남아있다. (그림 1)에서 언급한 것 처럼, graph $\mathrm{G}$ 의 attractor는 attractor 주변의 cluster를 생 성한다. 여기서 우리는 바인딩 영역에서 빈번하게 발견되는 잔기들을 attractor로 정의하고 이들에게 높은 값의 가중치 를 부여한다. 만약 대각선 셀에 더 큰 값을 할당한다면 이 는 attractor 역할을 하게 되고, 다른 node(잔기)와 높은 connectivity를 가지게 되어 이를 중심으로 클러스터가 형성 될 가능성이 크다. 우리는 대각선상의 셀 값에 일정한 값을 설정하기보다, 바인딩 영역의 잔기 빈발도를 계산하여, 대각 선상의 값을 설정하였다.

\section{1 바인딩 영역의 아미노산 빈발도}

단백질 상호작용은 결합하는 잔기를 포함하는 더 넓은 영 역에서 수행된다. 이 논문에서 결합하는 잔기 주변의 영역 을 바인딩 영역으로 정의한다. 단백질의 활성 사이트를 포 함하는 바인딩 영역은 단백질 표면에 위치하고, 잔기 구성 은 단백질 표면 전체와는 다르다. 바인딩 영역의 잔기 빈발 도를 계산하기 위해, 우리는 CSA [6] 데이터베이스로부터 94 개의 단일 체인 단백질의 활성사이트 잔기를 추출하였다. 표면 잔기를 추출하기 위해 RasMol [20] 프로그램을 사용하 였고, 각 활성사이트 잔기로부터 가장 근접한 20 개의 잔기 들을 선택하였다. 결국 선택된 잔기는 중복을 제거하고 바 인딩 영역을 형성한다.

잔기 빈발도를 계산하는 과정에서 우리는 표면보다 바인 딩 영역에서 더 빈발하게 발견되는 잔기를 조사하였다. 특 히 GLY(Glycine)은 바인딩 영역에서 가장 빈발하게 발견된 다. 그러나 GLY은 단백질 표면 전체에서도 가장 빈발하기 때문에 GLY의 빈발도 조정이 필요하다. 식 (3)은 아미노산 빈발도 $\mathrm{AA}_{\mathrm{i}}$ 의 계산 식이다.

$$
A A_{i}=\frac{\left(\sum_{a=1}^{N} A A_{i}(a) / \sum_{a=1}^{N} A A(a)\right)}{\left(\sum_{s=1}^{N} A A_{i}(s) / \sum_{s=1}^{N} A A(s)\right)}
$$

표면에서의 특정 잔기 빈발도 $\mathrm{AA}_{\mathrm{i}}$ 는 식 (3)의 분모에서 정의된다. $\mathrm{AA}(\mathrm{s})$ 는 한 단백질에서 표면 잔기의 전체 개수를 나타내고, $\mathrm{AA}_{\mathrm{i}}(\mathrm{s})$ 는 특정 잔기 $\mathrm{AA}_{i}$ 의 개수이다. 바인딩 영 역에서의 특정 잔기 $\mathrm{AA}_{\mathrm{i}}$ 빈발도는 식 (3)의 분자에서 정의 된다. $\mathrm{AA}(\mathrm{a})$ 와 $\mathrm{AA}_{\mathrm{i}}(\mathrm{a})$ 는 각각 바인딩 영역 잔기의 전체 개 수와 바인딩 영역의 특정 잔기 $\mathrm{AA}_{\mathrm{i}}$ 개수를 나타낸다.

(그림 6)는 식 (3)을 이용한 실험 결과를 나타낸다. (그림 6)에서 ' $\mathrm{AA}_{\mathrm{i}}=1.0$ '은 아미노산 $\mathrm{AA}_{\mathrm{i}}$ 가 바인딩 영역과 표면 에서 동일하게 빈발함을 의미한다. ' $\mathrm{AA}_{\mathrm{i}}<1.0$ '은 특정 잔기 가 바인딩 영역보다 표면에서 더 빈발한 것을 의미한다. 반 대로, 특정 잔기 $\mathrm{AA}_{\mathrm{i}}$ 가 표면보다 바인딩 영역에서 더 빈발 한 경우 ' $\mathrm{AA}_{\mathrm{i}}>1.0$ '의 결과를 가진다. 이 비율을 기반으로, 우리는 각 아미노산에 대한 가중치를 계산하고 (그림 5)의 대각선상의 값 설정 시 계산된 가중치를 사용한다. 


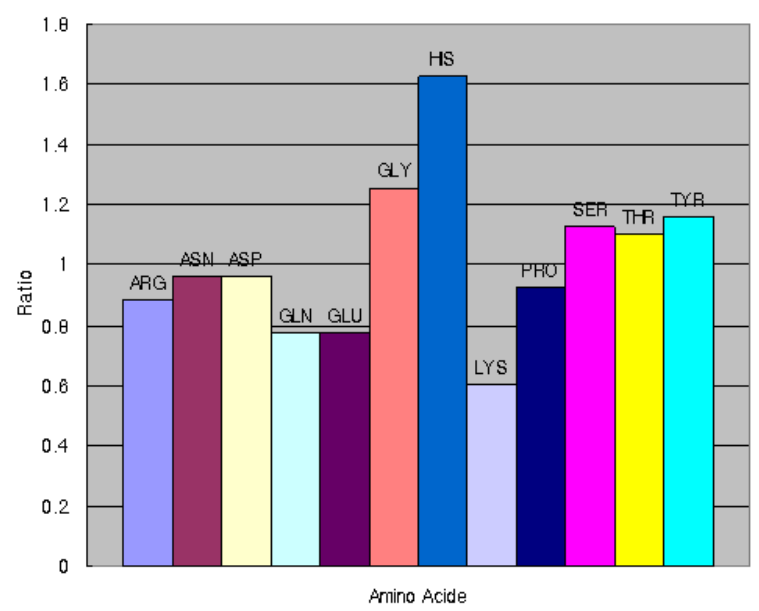

(그림 6) 아미노산 빈발도

\begin{tabular}{|c|c|c|c|c|c|c|}
\hline & aa1 & aa2 & aa3 & aa4 & aa5 & aa6 \\
\hline aa1 & $\mathrm{W}_{\text {aa1 }}$ & $1 / 5$ & $1 / 8$ & $1 / 12$ & $1 / 13$ & $1 / 3$ \\
\hline aa2 & $1 / 5$ & $\mathrm{~W}_{\text {aа2 }}$ & $1 / 6$ & $1 / 9$ & $1 / 8$ & $1 / 20$ \\
\hline aa4 & $1 / 8$ & $1 / 6$ & $\mathrm{~W}_{\text {aа3 }}$ & $1 / 3$ & $1 / 10$ & $1 / 16$ \\
\hline aa4 & $1 / 12$ & $1 / 9$ & $1 / 3$ & $\mathrm{~W}_{\text {aa4 }}$ & $1 / 2$ & $1 / 8$ \\
\hline aa5 & $1 / 13$ & $1 / 8$ & $1 / 10$ & $1 / 2$ & $\mathrm{~W}_{\text {aа5 }}$ & $1 / 5$ \\
\hline aa6 & $1 / 3$ & $1 / 20$ & $1 / 16$ & $1 / 8$ & $1 / 5$ & $\mathrm{~W}_{\text {aа6 }}$ \\
\hline
\end{tabular}

(그림 7) diagonal value 이용한 connectivity Graph Matrix GM

실험 결과에서 알 수 있듯이, HIS (Histidine), GLY (Glycine), TYR (Tyrosine), SER (Serine)은 LYS (Lysine), GLU (Glutamic acid), GLN (Glutamine)보다 더 높은 가중 치를 가진다. (그림 7)은 connectivity Graph Matrix GM으 로 변환된 distance matrix를 보여주고, $\mathrm{W}_{\text {aan }}$ 은 특정 아미노 산에 대한 가중치를 나타낸다. (그림 8)은 이 논문에서 사용 된 $\mathrm{MCL}$ process의 전체적인 단계이다.

\section{Validation}

우리는 94 개의 단백질을 이용하여 $\mathrm{MCL}$ 알고리즘의 inflation factor와 3장에서 언급한 distance cut-off를 다양하 게 설정하였다. 그리고 단백질 표면의 활성 사이트 주변에 위치하는 유효 클러스터를 생성하는 단백질의 수와 바인딩
영역에 위치하는 유효 클러스터의 precision을 계산하였다. 제안하는 방법의 검증을 위하여 다음과 같은 바인딩 영역의 정의를 요한다.

【정의 $1 】$ 바인딩 영역

바인딩 영역은 활성사이트 잔기주변의 잔기를 지칭하는 용어로써 활성사이트 각 잔기 당 가장 가까운 20 개의 잔기 를 취한다. 단백질 마다 활성사이트를 이루는 잔기 수는 다 양하므로, 바인딩 영역의 크기(잔기의 개수)를 고려할 때, 각 잔기별로 중복된 잔기들은 제거되어 카운트 된다.

\subsection{DataSet}

우리는 CSA [6] 데이터베이스로부터 94개 단일 체인 효 소를 추출하였다. Catalytic Site Atlas (CSA)는 효소의 3차 원 구조상의 촉매 잔기와 활성 사이트 정보를 제공하는 데 이터베이스이다. CSA 데이터베이스는 효소가 일으키는 촉 매 작용의 종류에 따라, 작용에 관여하는 촉매 잔기를 분류 하였다. RasMol [20] 프로그램은 표면 잔기를 추출하기 위 해 사용되었고, 각 바인딩 잔기와 가장 근접한 20 개 잔기를 선택하였다. 중복을 제거한 잔기는 우리가 정의한 바인딩 영역을 형성한다.

\section{2 유효 클러스터}

유효 클러스터를 평가하기 위해 클러스터의 precision과 cluster score를 제시하였다. cluster score는 각 아미노산의 가중치로부터 계산된다. 바인딩 영역에서 빈발하는 잔기로 구 성된 클러스터는 평균적으로 높은 가중치들을 갖는다(식 4).

$$
\text { cluster score }=\frac{\sum_{i=1}^{n}\left(W_{a a 1}+W_{a a 2}+\cdots+W_{a a n}\right)}{n}
$$

\section{【정의2】 유효 클러스터}

$\mathrm{MCL}$ 의 결과로서 제시된 클러스터 중 cluster score 가 높고, 클러스터의 precision이 높은 클러스터를 나타낸다. 각 클러스터의 cluster score는 식 (4)로 계산되고, precision은 식 (5)로 계산된다.

【정의3】 대표 클러스터

하나의 단백질은 inflation과 distance cut-off에 따라 여 러 개의 유효 클러스터를 가질 수 있고 이중 가장 좋은 precision을 갖는 클러스터를 그 단백질의 대표 클러스터라

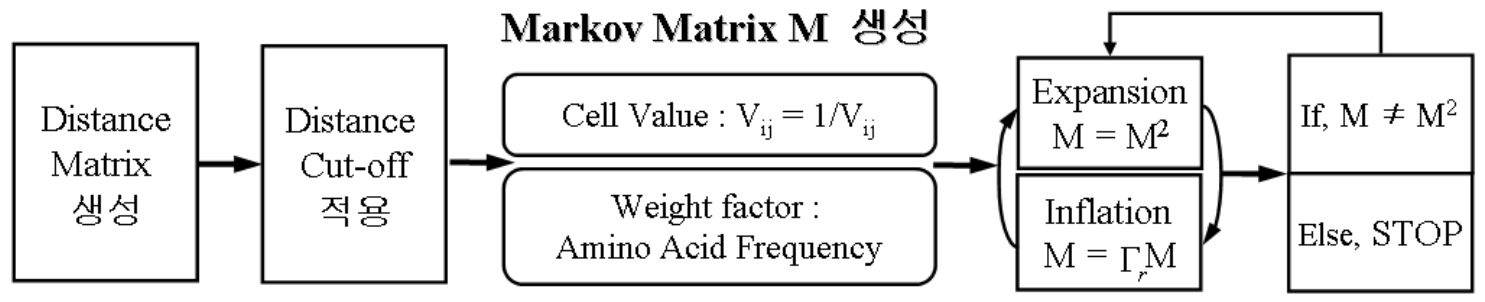

(그림 8) MCL 알고리즘을 적용한 프레임 워크 


\section{고 정의한다.}

다른 평가 기준은 cluster의 precision이다. cluster의 잔기 중 바인딩 영역의 잔기는 true positive 잔기로 분류되고, 그 외의 잔기는 cluster에 의해 잘못 바인딩 영역의 잔기로 분 류된 false positive이다. 따라서 바인딩 영역의 잔기를 많이 포함하는 cluster일 수록 높은 precision을 갖는다(식 5).유효 클러스터는 정의 2에 따라 best 또는 second cluster score 와 특정 inflation factor 와 distance cut-off를 적용 했을 때, 가장 좋은 precision을 갖는 cluster를 의미한다. 94개 단 백질 중, 우리가 제시한 방법은 best cluster score의 유효 클 러스터를 갖는 68 개 단백질(72\%)을 산출하였다. <표 $1>$ 에서 best cluster score를 이용하여 검출된 68개 단백질의 'cluster score' 열은 'Best'로 나타내었다. Second cluster score를 갖 는 cluster가 유효 클러스터로 분류된다면, 91개 단백질 (97\%)이 예측된다. Second cluster score을 이용하여 검출된 23 개 단백질은 <표 1>의 'cluster Score'에서 값 'Second'로 나타내었다.

$$
\text { Precision }=\frac{T P}{T P+F P}
$$

우리는 9개의 distance cut-off value (11 19 $\AA$ )와 8개 inflation factor (1.2 1.9)를 조합하여 94개 단백질을 실험하

〈표 1〉 단일 체인 효소 DataSet의 94개 단백질 분류와 실험 결과

\begin{tabular}{|c|c|c|c|c|c|}
\hline Ec num & $\begin{array}{l}\text { Pdb } \\
\text { code }\end{array}$ & $\begin{array}{c}\text { Representative } \\
\text { Precision }\end{array}$ & $\begin{array}{l}\text { Active } \\
\text { Site }\end{array}$ & $\begin{array}{l}\text { Cluster } \\
\text { Score }\end{array}$ & Description \\
\hline \multicolumn{6}{|c|}{ Oxidoreductases : 15} \\
\hline 1.1.1.2 & 2alr & 0.92 & In & Best & Aldehyde reductase \\
\hline 1.1.1.158 & $1 \mathrm{mbb}$ & 0.5 & In & Second & Uridine Diphospho-N-Acetylenolpyruvylglucosamine \\
\hline 1.5.1.3 & $1 \mathrm{ra} 2$ & 0.93 & In & Best & Dihydrofolate reductase \\
\hline 1.5.1.3 & 1vie & 1.0 & In & Best & Dihydrofolate reductase \\
\hline 1.5.1.28 & $\operatorname{lbg} 6$ & 1.0 & In & Best & $\mathrm{N}$-(1-d-carboxylethyl)-1-norvaline dehydrogenase \\
\hline 1.7.2.1 & 1nid & 1.0 & In & Best & Nitrite reductase \\
\hline 1.7.3.3 & luox & 0.7 & In & Second & Urate oxidase \\
\hline 1.8.1.2 & 1aop & 0.72 & In & Best & Sulfite reductase hemoprotein \\
\hline 1.11.1.10 & $1 \mathrm{a} 8 \mathrm{q}$ & 0.9 & In & Best & Bromoperoxidase A1 \\
\hline 1.11.1.10 & $1 \mathrm{vnc}$ & 1.0 & In & Best & Vanadium-containing chloroperoxidase \\
\hline 1.11.1.10 & $2 \mathrm{cpo}$ & Not & detected & & Chloroperoxidase \\
\hline 1.13.12.7 & 1lci & 0.53 & In & Best & Luciferase \\
\hline 1.14.15.1 & lakd & 0.57 & In & Second & Cytochrome p450cam \\
\hline 1.15.1.1 & 1eso & 1.0 & Out & Second & $\mathrm{Cu}, \mathrm{Zn}$ superoxide dismutase \\
\hline 1.15.1.1 & $2 \mathrm{jcw}$ & 0.81 & In & Best & $\mathrm{Cu} / \mathrm{zn}$ superoxide dismutase \\
\hline \multicolumn{6}{|c|}{ Transferases : 17} \\
\hline 2.1.1.6 & 1vid & 0.89 & In & Best & Catechol $\quad \mathrm{O}^{-}$-methyltransferase \\
\hline 2.1.1.45 & $11 \mathrm{cb}$ & 0.91 & In & Best & Thymidylate synthase \\
\hline 2.1.1.80 & $1 \mathrm{af} 7$ & 0.92 & In & Best & Chemotaxis receptor methyltransferase cher \\
\hline 2.1.4.1 & $1 \mathrm{jdw}$ & 0.68 & In & Best & L-arginine-glycine $\quad$ amidinotransferase \\
\hline 2.3.1.39 & $1 \mathrm{mla}$ & 1.0 & In & Best & Malonyl-coenzyme a acyl carrier protein transacylase \\
\hline 2.3.1.41 & 1 kas & 0.42 & Out & Second & Beta-ketoacyl acp synthase ii \\
\hline 2.3.1.117 & $2 \mathrm{tdt}$ & 0.92 & In & Best & Tetrahydrodipicolinate $\quad n$-succinyltransferase \\
\hline 2.3.1.129 & $11 \mathrm{xa}$ & 0.92 & In & Best & Udp $\quad n^{-}$acetylglucosamine $\mathrm{o}^{-}$-acyltransferase \\
\hline 2.3.3.1 & $1 \mathrm{al6}$ & 0.75 & In & Best & Citrate synthase \\
\hline 2.4.2.29 & 1pud & 0.83 & In & Best & Trna-guanine transglycosylase \\
\hline 2.4.2.30 & $1 \mathrm{a} 26$ & 0.92 & In & Best & Poly (adp-ribose) polymerase \\
\hline 2.5.1.7 & 1uae & 1.0 & Out & Second & Udp-n-acetylglucosamine enolpyruvyl transferase \\
\hline 2.5.1.15 & 1aj0 & 0.8 & In & Best & Dihydropteroate synthase \\
\hline 2.7.3.3 & $\operatorname{lbg} 0$ & 0.71 & In & Second & Arginine kinase \\
\hline 2.7.4.3 & 1zio & 1.0 & In & Best & Adenylate kinase \\
\hline 2.7.6.3 & 1hka & 0.94 & In & Second & 6-hydroxymethyl-7,8-dihydropterin \\
\hline 2.8.1.1 & 1rhs & 0.94 & In & Best & Sulfur-substituted rhodanese \\
\hline
\end{tabular}


〈표 1〉계속

\begin{tabular}{|c|c|c|c|c|c|}
\hline Ec num & $\begin{array}{l}\text { Pdb } \\
\text { code } \\
\end{array}$ & $\begin{array}{c}\text { Representative } \\
\text { Precision } \\
\end{array}$ & $\begin{array}{c}\text { Active } \\
\text { Site } \\
\end{array}$ & $\begin{array}{c}\text { Cluster } \\
\text { Score } \\
\end{array}$ & Description \\
\hline Hydrolases & 42 & & & & \\
\hline 3.1.1.- & lagy & 1.0 & In & Best & Cutinase \\
\hline 3.1.1.3 & 2lip & 0.68 & Out & Best & Lipase \\
\hline 3.1.1.6 & 1bs9 & 1.0 & In & Best & Acetyl xylan esterase \\
\hline 3.1.1.7 & 2ace & 0.75 & In & Second & Acetylcholinesterase \\
\hline 3.1.1.29 & 2 pth & 0.67 & In & Best & Peptidyl-trna hydrolase \\
\hline 3.1.1.45 & 1din & 0.62 & Out & Best & Dienelactone hydrolase \\
\hline 3.1.1.47 & 1bwp & 0.58 & In & Best & Platelet-activating factor acetylhydrolase \\
\hline 3.1.1.61 & 1chd & 1.0 & In & Best & Cheb methylesterase \\
\hline 3.1.3.5 & 1ush & 0.89 & In & Second & $5^{\prime}$-nucleotidase \\
\hline 3.1.3.48 & $1 y t w$ & 0.95 & In & Second & Yersinia protein tyrosine phosphatase \\
\hline 3.1.4.3 & 1ah7 & 0.55 & In & Best & Phospholipase c \\
\hline 3.1.6.8 & lauk & 1.0 & In & Best & Arylsulfatase a \\
\hline 3.1.11.2 & 1ako & 1.0 & In & Best & Exonuclease iii \\
\hline 3.1.21.4 & $1 \mathrm{cfr}$ & 0.71 & In & Second & Restriction endonuclease \\
\hline 3.1.30.1 & $1 \mathrm{ak} 0$ & 0.93 & In & Best & P1 nuclease \\
\hline 3.1.31.1 & $1 \mathrm{a} 2 \mathrm{t}$ & 1.0 & In & Best & Staphylococcal nuclease \\
\hline \multicolumn{6}{|c|}{ Hydrolases (continued) } \\
\hline 3.2.1.4 & 2eng & 0.78 & In & Best & Endoglucanase V \\
\hline 3.2.1.8 & $1 b v v$ & 0.48 & In & Second & Endo-1,4-beta-xylanase \\
\hline 3.2.1.8 & $1 \exp$ & 1.0 & In & Best & Beta-1,4-d-glycanase $\quad$ cex-cd \\
\hline 3.2.1.8 & 2his & 0.76 & Out & Second & Cellulomonas fimi family 10 beta-1,4-glycanase \\
\hline 3.2.1.10 & luok & 0.83 & In & Best & Oligo-1,6-glucosidase \\
\hline 3.2.1.17 & 2061 & 0.35 & In & Best & Lysozyme \\
\hline 3.2.1.18 & leuu & 0.61 & In & Second & Sialidase \\
\hline 3.2.1.18 & $7 \mathrm{nn} 9$ & 1.0 & In & Best & Neuraminidase N9 \\
\hline 3.2.1.21 & $1 \mathrm{cbg}$ & 0.83 & In & Best & Cyanogenic beta-glucosidase \\
\hline 3.2.1.60 & 2amg & 0.94 & In & Best & 1,4-alpha-d-glucan maltotetrahydrolase \\
\hline 3.2.1.68 & $1 \mathrm{bf} 2$ & \multicolumn{3}{|c|}{ Not detected } & Isoamylase \\
\hline 3.2.3.1 & 1 myr & 0.91 & In & Best & Myrosinase \\
\hline 3.4.11.1 & 1lam & 0.71 & In & Best & Leucine aminopeptidase \\
\hline 3.4.11.9 & $1 \mathrm{a} 16$ & 0.8 & In & Best & Aminopeptidase $\mathrm{p}$ \\
\hline 3.4.17.8 & 1lbu & 0.94 & In & Best & Muramoyl-pentapeptide carboxypeptidase \\
\hline 3.4.19.12 & luch & 1.0 & Out & Best & Ubiquitin $\quad c-$ terminal hydrolase $u c h-13$ \\
\hline 3.4 .22 .40 & $1 \mathrm{gcb}$ & 0.79 & In & Second & Gal6 hg (emts) derivative \\
\hline 3.4.23.1 & $1 \mathrm{am} 5$ & 1.0 & In & Second & Pepsin \\
\hline 3.4.24.17 & 1hfs & 0.56 & In & Second & Stromelysin-1 \\
\hline 3.4 .24 .17 & $1 \mathrm{slm}$ & 0.69 & In & Best & Stromelysin-1 \\
\hline 3.4 .24 .36 & $11 \mathrm{ml}$ & 0.52 & In & Best & Leishmanolysin \\
\hline 3.6.1.3 & $1 \mathrm{kaz}$ & 0.63 & Out & Best & 70kd heat shock cognate protein \\
\hline 3.6.1.7 & 2acy & 1.0 & In & Second & Acylphosphatase \\
\hline 3.6.1.29 & 5 fit & 0.95 & In & Best & Fragile histidine triad protein \\
\hline 3.6.4.6 & lnsf & 1.0 & In & Best & $\mathrm{N}$-ethylmaleimide sensitive factor \\
\hline 3.8.1.5 & $1 b 6 g$ & 1.0 & In & Best & Haloalkane dehalogenase \\
\hline Lyases : & 10 & & & & \\
\hline 4.1.1.7 & 1bfd & 0.61 & In & Best & Benzoylformate decarboxylase \\
\hline 4.1.1.49 & 1aq2 & 0.5 & In & Second & Phosphoenolpyruvate carboxykinase \\
\hline 4.1.2.17 & 1fua & 1.0 & In & Best & L-fuculose-1-phosphate aldolase \\
\hline 4.1.2.25 & $2 \mathrm{dhn}$ & 0.67 & In & Best & 7,8-dihydroneopterin aldolase \\
\hline 4.2.2.15 & 1sll & 0.79 & In & Second & Sialidase 1 \\
\hline 4.2.3.9 & 5eat & 1.0 & In & Best & 5-epi-aristolochene synthase \\
\hline 4.2.99.18 & 1bix & 1.0 & In & Best & Ap endonuclease 1 \\
\hline 4.2.99.18 & 2abk & 0.51 & In & Best & Endonuclease iii \\
\hline 4.3.1.19 & $1 \mathrm{tdj}$ & 0.8 & In & Best & Biosynthetic threonine deaminase \\
\hline 4.6.1.13 & 2plc & 1.0 & In & Best & Phosphatidylinositol-specific phospholipase c \\
\hline
\end{tabular}


〈표 1〉계속

\begin{tabular}{|c|c|c|c|c|c|c|}
\hline Ec num & $\begin{array}{r}\text { Pdb } \\
\text { code } \\
\end{array}$ & $\begin{array}{c}\text { Representative } \\
\text { Precision } \\
\end{array}$ & $\begin{array}{l}\text { Active } \\
\text { Site } \\
\end{array}$ & $\begin{array}{c}\text { Cluster } \\
\text { Score } \\
\end{array}$ & \multicolumn{2}{|l|}{ Description } \\
\hline \multicolumn{7}{|c|}{ Isomerases $: 3$} \\
\hline 5.3.1.8 & $1 \mathrm{pmi}$ & 0.92 & In & Best & Phosphomannose isomerase & \\
\hline 5.3.1.24 & 1nsj & 0.70 & In & Best & Phosphoribosyl anthranilate isomerase & \\
\hline 5.99 .1 .3 & $1 \mathrm{ab} 4$ & 1.0 & In & Best & Gyrase A & \\
\hline \multicolumn{7}{|c|}{ Ligases : 7} \\
\hline 6.1.1.10 & $1 \mathrm{a} 8 \mathrm{~h}$ & 0.92 & In & Second & Methionyl-trna synthetase & \\
\hline 6.3.2.3 & 1gsa & 0.63 & Out & Best & Glutathione synthetase & \\
\hline 6.3.2.4 & $2 \mathrm{~d} \ln$ & 1.0 & In & Best & $\mathrm{D}^{-}$-alanine $\mathrm{e}^{--} \mathrm{d}$-alanine ligase & \\
\hline 6.3 .2 .9 & luag & 0.78 & In & Best & Udp-n-acetylmuramoyl-1-alanine-:d-glutamate & ligase \\
\hline 6.3.3.3 & 1dae & 0.59 & In & Best & Dethiobiotin synthetase & \\
\hline 6.3.4.4 & lgim & 0.74 & In & Second & Adenylosuccinate synthetase & \\
\hline 6.5.1.1 & $1 \mathrm{a} 0 \mathrm{i}$ & No & etected & & DNA ligase & \\
\hline
\end{tabular}

였다. 따라서 모든 단백질은 72 개 조합으로 실험되었고, 각 단백질에 대한 유효 클러스터는 distance cut-off와 inflation factor의 조합에 따라 한 개 이상이 될 수 있다. 각 단백질의 유효 클러스터 개수는 second cluster score를 갖는 cluster를 고려하면 더 증가된다. 우리는 각 단백질의 대표적인 best cluster를 조사하였고, 대표 클러스터는 정의 3에서 나타내는 바와 같다. 이 과정에서 우리는 낮은 true positive 잔기 개수 $(<9)$ 를 갖는 cluster를 제거하였고, 가장 좋은 precision을 갖는 cluster를 선택하였다. 여기서, 한 개 이상의 대표 클러 스터를 갖는 단백질도 23 개나 됨을 발견하였다.

예를 들어, ' $1 \mathrm{mla}$ '는 best cluster score만 고려한다면 6개 조합을 갖는다. 만약 second cluster score도 고려한다면, 유 효 클러스터를 생성하는 조합의 수는 23 개로 증가한다. ' $1 \mathrm{mla}$ '는 radius $=12 \AA$ 와 inflation $=1.7$ 또는 1.8 의 2 개 조 합으로의 대표 클러스터를 갖고, 두 조합의 precision은 동 일하게 1.0 이다. <표 2>는 91개 단백질의 대표 클러스터 133 개의 distance cut-off value와 inflation factor 빈발 조합

〈표 2〉대표 클러스터의 빈발 조합

\begin{tabular}{ccc}
\hline $\begin{array}{c}\text { Distance } \\
\text { Cut-off }\end{array}$ & Inflation & $\begin{array}{c}\text { No. of representative } \\
\text { Clusters }\end{array}$ \\
\hline \hline 11 & 1.8 & 18 \\
11 & 1.7 & 13 \\
12 & 1.7 & 12 \\
11 & 1.6 & 11 \\
12 & 1.5 & 9 \\
12 & 1.6 & 8 \\
11 & 1.5 & 8 \\
12 & 1.8 & 6 \\
14 & 1.7 & 5 \\
14 & 1.8 & 5 \\
11 & 1.4 & 5 \\
13 & 1.7 & 4 \\
13 & 1.6 & 4 \\
16 & 1.8 & 4 \\
13 & 1.8 & 4 \\
14 & 1.6 & 4 \\
17 & 1.8 & 4 \\
\hline
\end{tabular}

을 보여준다. 또한 <표 3>에서는 가장 높은 20 개의 유효 클 러스터들의 빈발 조합을 나타낸다. 91개 단백질의 대표 클

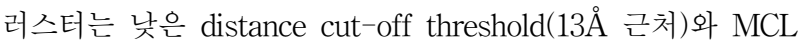
알고리즘의 높은 inflation factor(1.7 근처) 일 경우 형성된 다. <표 3>의 유효 클러스터의 빈발 조합의 경우도 이와 같 은 양상을 나타내었다. 표 1의 'Representative Precision' 열 은 대표 cluster의 precision이고, 평균 precision은 ‘0.83'이다. 또한 대표 클러스터가 활성사이트를 포함하는 경우 <표 1> 에서, Active Site 필드에 'In'으로 표기 하였고, 포함하지 않 은 경우는 'Out'로 표기하였다.

효소의 활성 사이트는 일반적으로 'cleft' 또는 'cavity'라고 불리는 오목한 영역에 위치한다[21]. 따라서 (그림 9(a))의 어 두운 부분처럼, 바인딩 영역도 오목한 영역에 위치한다.

cleft나 cavity를 추출하는 프로그램[10, 22]은 이미 소개 되었다. 우리의 실험 결과에서 흥미로운 점은 단백질의 대

〈표 3〉 유효 클러스터의 빈발 조합

\begin{tabular}{cccc}
\hline $\begin{array}{c}\text { Distance } \\
\text { Cut-off }\end{array}$ & Inflation & No. of Valid Cluster & Ratio of Valid Cluster \\
\hline \hline 13 & 1.7 & 58 & $64 \%$ \\
14 & 1.8 & 58 & $64 \%$ \\
13 & 1.8 & 56 & $62 \%$ \\
11 & 1.5 & 55 & $60 \%$ \\
12 & 1.6 & 54 & $59 \%$ \\
12 & 1.7 & 53 & $58 \%$ \\
14 & 1.7 & 53 & $58 \%$ \\
11 & 1.7 & 50 & $55 \%$ \\
13 & 1.6 & 49 & $54 \%$ \\
12 & 1.8 & 48 & $53 \%$ \\
15 & 1.8 & 48 & $53 \%$ \\
12 & 1.5 & 47 & $52 \%$ \\
16 & 1.8 & 47 & $52 \%$ \\
11 & 1.4 & 46 & $51 \%$ \\
14 & 1.6 & 46 & $51 \%$ \\
11 & 1.8 & 45 & $49 \%$ \\
15 & 1.7 & 42 & $46 \%$ \\
11 & 1.6 & 41 & $45 \%$ \\
13 & 1.5 & 41 & $45 \%$ \\
17 & 1.8 & 40 & $44 \%$ \\
\hline
\end{tabular}


표 cluster는 (그림 9(b))에서 볼 수 있듯이, cleft나 cavity 이외의 영역에서도 발견이 된다는 점이다. 즉, 우리의 방법 은 cavity나 cleft 추출하는 기존의 툴에서 발견할 수 없는 바인딩 잔기를 추출할 수 있다.

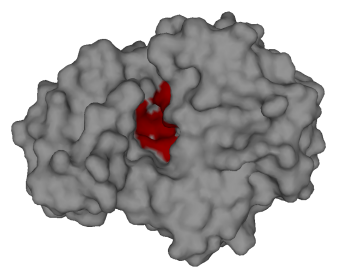

(a) $1 \mathrm{mla}$

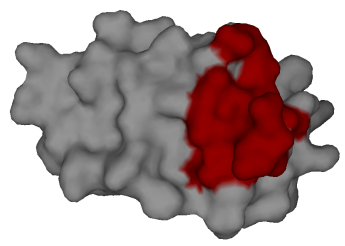

(b)2acy
(그림 9) 대표 클러스터의 예

\section{6. 결 론}

단백질 기능을 예측하기 위해 단백질의 구조와 서열 분석 이 수행되어 왔다. 서열 분석은 서열 상동성을 통해 단백질 기능을 예측한다. 그러나 유사한 폴드 또는 서열을 갖지만 다 른 기능을 수행하는 단백질이 밝혀졌다. 그리고 폴드가 유사 하지만 활성 사이트가 다르다면 다른 기능을 수행할 수 있다.

이 논문에서 우리는 $\mathrm{MCL}$ process와 함께 잔기 간의 connvectivity를 이용하여, 단백질 표면의 활성 사이트 주변 에 위치하는 바인딩 영역을 예측하는 방법을 제시하였다. distance matrix에서 의미있는 distance value만을 선택하기 위하여 distance cut-off value를 다양하게 적용하였고, $\mathrm{MCL}$ 알고리즘의 다양한 inflation factor를 이용하여 실험하 였다. CSA 데이터 (94개 단일 체인 단백질)를 이용한 실험 결과, 제시한 방법은 91 개 단백질에서 표면의 활성 사이트 주변에 위치하는 바인딩 영역을 추출하였다. 대표 cluster는 평균 $83 \%$ precision의 결과를 산출하였다. 또한 실험으로 원 하는 결과를 가진 클러스터는 비교적 낮은 distance cut-off threshold( $13 \AA$ 근처)와 $\mathrm{MCL}$ 알고리즘의 높은 inflation factor (1.7 근처) 일 경우 형성되었음을 보였다.

이 논문에서 우리는 distance matrix의 잔기 연결 정보를 이용하여 새로운 기하학적 특징을 제시하였다. 우리의 연구 는 활성사이트와 관련 없는 잔기는 제거하고 활성 사이트 주변의 잔기를 선택함으로써 활성 사이트 잔기를 예측하는 데 이용할 수 있다. 또한, 제시한 방법은 기존의 cavity 또 는 cleft 추출 툴은 검출이 불가능한 표면상 볼록한 부분의 바인딩 영역또한 검출 할 수 있는 장점이 있다.

\section{참 고 문 헌}

[1] A.Stark, A.Shkumatov, "Finding Functional Sites in Structural Genomics," Proteins. Structure, Vol.12, pp.1205-1412, 2004.

[2] L.M. Kauvar and H.O. Villar, "Deciphering cryptic similarities in protein binding sites," Curr. Opin.
Biotechanol., Vol.9, pp.390-394, 1998.

[3] P.C Babbitt, "Definition of enzyme function for the structural genomics era," Curr. Opin, Chem. Biol., Vol.7, pp.230-237, 2003.

[4] S. Van Dongen, "Graph clustering by flow simulation," $\mathrm{PhD}$ thesis, University of Utrecht, The Netherlands, 2000.

[5] A.J. Enright, S.Van Dongen and C.A. Ouzounis, "An efficient algorithm for large-scale detection of protein families," Nucleic Acids Research, Vol.30, No.7, pp. 1575-1584, 2002.

[6] C.T. Porter, G.J. Bartlett, and J.M. Thornton, "The Catalytic Site Atlas: a resource of catalytic sites and residues identified in enzymes using structural data," Nucl. Acids. Res., Vol.32, pp.129-133, 2004.

[7] Reichmann D, Rahat O, Cohen M, Neuvirth H, Schreiber G., "The molecular architecture of protein-protein binding sites," Curr Opin Struct Biol., Vol.17, No.1, pp.67-76, 2007.

[8] A. Via, F. Ferre, B. Brannetti, A. Valencia, and M. Helmer-Citterich, "Three-dimensional view of the surface motif associated with the P-loop structure: cis and trans cases of convergent evolution," J. Mol. Biol., Vol.303, pp.455-465, 2000.

[9] Fabian Glaser, Richard J. Morris, Rafael J. Najmanovich, Roman A. Laskowski, and Janet M. Thornton, "A Method for Localizing Ligand Binding Pockets in Protein Structures.," PROTEINS: Structure, Function, and Bioinformatics Vol.62, pp.479 - 488, 2006.

[10] R.A. Laskowski, "SURFNET: A program for visualizing molecular surfaces, cavities, and intermolecular interactions," J.Mol.Graph, Vol.13, pp.307-308, 1995.

[11] Changhui Yan, Vasant Honavar, and Drena Dobbs, "Predicting Protein-Protein Interaction Sites From Amino Acid Sequence," Department of Computer Science Iowa State University, 2002.

[12] T.Andrew Binkowski, Larisa Adamian and Jie Liang, "Inferring Functional Relationships of Proteins from Local Sequence and Spatial Surface Patterns," J.Mol.Biol. Vol.332, pp.505-526, 2003.

[13] Oliviero Carugo and Giacomo Franzot, "Prediction of protein-protein interactions based on surface patch comparison,” Proteomics, Vol.4, pp.1727-1736, 2004.

[14] Susan Jones and Janet M.Thornton, "Principles of protein-protein interactions," Proc. Natl. Acad. Sci. USA, Vol.93, pp.13-20, 1996.

[15] L.Mirny and E.Domany, "Protein Fold Recognition and Dynamics in the Space of Contact Maps," Proteins, pp.391-410, 1996.

[16] M.Vendruscolo, E.Kussell and E.Domany, "Recovery of Protein Structure from Contact Maps," Fold. Des, pp.295-306, 1997. 
[17] G. Lancia, R. Carr, B. Walenz, and S.Istrail, "101 optimal PDB structure alignments : a branch-and-cut algorithm for the maximum contact map overlap problem," Proceedings of The Fifth Annual International Conference on Computational Molecular Biology, RECOMB, 2001.

[18] B. Carr, W. E. Hart, N. Krasnogor, E. K. Burke, J. D. Hirst, and J. E. Smith, "Alignment of protein structures with a memetic evolutionary algorithm." In GECCO-2002: Proceedings of the Genetic and evolutionary Computation Conference, Morgan Kaufman, 2002.

[19] E.L.L. Sonnhammer and J.C. Wooton, "Dynamic contact maps of protein structures," Journal of Molecular Graphics and Modelling, Vol.16, pp.1-5, 1998.

[20] http://www.umass.edu/microbio/rasmol/index2.htm

[21] R.A. Laskowski, N.MLuscombe, M.B.Swindells and J.M.Thornton, "Protein clefts in molecular recognition and function," Protein Science, Vol.5, pp. 2438-2452, 1996.

[22] http://xray.bmc.uu.se/usf/voidoo.html.

[23] 김선신, 정광수, 류근호, “단백질 구조기반 단백질 간의 기 능관계 예측 기법,” 한국정보처리학회, 12 권 2호, pp.55-58, 2005.

[24] Kwang Su Jung, Sunshin Kim, Keun Ho Ryu, "A Personalized Biological Data Management System based on BSML," LNBI, vol.4115, pp.362-371, 2006.

[25] Sunshin Kim, Kwang Su Jung, Keun Ho Ryu, "Automatic Orthologous-Protein-Clustering from Multiple Complete-Genomes by the Best Reciprocal BLAST Hits," LNBI, Vol.3916, pp.60-70, 2006.

[26] 유기진, 정광수, 류근호, “잔기 위치 예측을 위한 단백질 기 하학적 특징 추출 기법,” 한국정보처리학회, 13 권 2호, pp.673-676, 2006.

[27] Kwang Su Jung, Ki Jin Yu, Keun Ho Ryu, Yong Je Chung, "Predicting Ligand Binding Site Using Protein Surface Features," PACIFIC SYMPOSIUM ON BIOCOMPUTING, pp.72, 2007.

[28] 유기진, 정광수, 류근호, 정용제, “단백질 활성 사이트 비교 를 통한 단백질 기능 예측 기법 설계,” 한국데이터베이스 학회, pp.191-197, 2007.

[29] 김선신, 이충세, 류근호, "유전체 상호간의 BLAST 최대 히트를 사용하여 서열화가 완성된 다수의 유전체로부터 Orthologous 단백질그룹을 자동적으로 클러스터링하는 기 법, 한국정보처리학회논문지D, 13D권 2호, pp.207-214, 2006.

[30] 김선신, 이범주, 정광수, 김영창, 김태경, 조완섭, 이충세, 류 근호, "다종의 유전체로부터 탐지된 올소로그(Ortholog)군 집에 대한 분석,” 한국정보과학회논문지 출판예정, 2008.

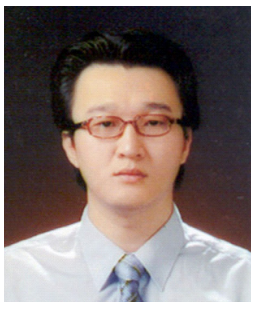

\section{정 광 수}

e-mail : ksjung@dblab.chungbuk.ac.kr 2001년 충북대학교 화학공학부(공학사)

2004년 충북대학교 정보산업공학과 (공학석사)

2006년 충북대학교 대학원 전자계산학과 박사수료

관심분야:Bioinformatics, 단백질 서열 및 구조, 생명정보 데이터베이스, 데이터마이닝

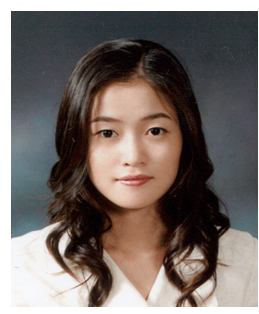

\section{유 기 진}

e-mail : heyu4580@dblab.chungbuk.ac.kr 2006년 충북대학교 생물학과(학사)

2006년 충북대학교 대학원 전자계산학과 입학

2006년 현 재 충북대학교 대학원 전자계산학과 석사과정

관심분야 : 바이오인포메틱스, 단백질 구조, 데이터마이닝

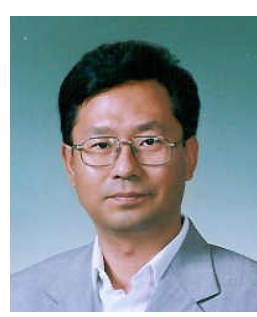

\section{정 용 제}

e-mail :chungyj@chungbuk.ac.kr 1979년 연세대학교 이과대학 화학과 (학사)

1981년 서울대학교 대학원 화학과 (이학석사)

1989년 미국 피츠버그대학교 결정학과 (이학박사)

1989년 1991년 피츠버그대학교 박사후연구원 1991년 현 재 충북대학교 생명과학부 교수 관심분야: $\mathrm{X}$-선 결정학, 단백질표면구조 분석 및 예측 등

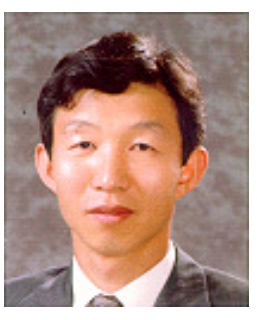

\section{류 근 호}

email : khryu@dblab.chungbuk.ac.kr 1976년 숭실대학교 전산학과(이학사) 1980년 연세대학교 공업 대학원 전산전공(공학석사)

1988년 연세대학교 대학원 전산전공(공학박사)

1976년 1986년 육군 군수 지원사 전산실(ROTC 장교), 한국전자통신연구소(연구원), 한국 방송대학교 전산학과(조교수) 근무

1989년 1991년 University of Arizona, Research Staff(TempIS 연구원, Temporal DB)

1986년 현 재 충북대학교 전기전자컴퓨터 공학부 교수 관심분야: 시간 데이터베이스, 시공간 데이터베이스, Temporal GIS, 지식기반 정보검색 시스템, 유비쿼터스컴퓨팅 및 스트림데이터처리, 데이터마이닝, 데이터베이스 보안, 바이오인포메틱스 등 